\title{
John Calam \\ Affecting Eternity: Origins of the University of \\ British Columbia's Faculty of Education.
}

Pacific Educational Press, 2007. 336 pp.

\section{Eric MacPherson \\ University of Manitoba}

Even a reading, let alone a review, of John Calam's excellent treatment of the founding of the Faculty of Education at the University of British Columbia had best begin with more than a casual look at the context of that event. That context bears on both the style and the contents of Calam's account.

For over two millennia, one of the more popular indoor sports has been the viewing of schools and teaching with alarm; declaiming that both have lost many of the admirable qualities they once had and are in serious need of repair. As this review is written, we are at the crest of a tsunami of enthusiasm for that game. Beginning with "A Nation at Risk" (1983) and culminating in "No Child Left Behind" (2002) and the 2008 proposals for its revision, it has become a commonplace that North American schools and teaching are almost beyond repair.

So as to appreciate Calam's work, one must shake off that fixation on the negative and reflect that there have been eras in which, instead, the zeitgeist has emphasized progress and optimism. One such wave began in the 1950s. Likely on account of a confluence of post-war relief, an unexpected economic surge, the baby boom, and the stimulus of Sputnik and the Apollo missions, then and for a few decades thereafter the attention of educators, the media, and the public at large was not centered on the virtues of a mythical past but on all those ways we could and were building a better educational system, beginning with a massive infusion of funding for curricular reform in the alphabet soup projects.

\section{Preview}

We begin, then, with a preview of a shelf of books only partially written to date. 
Its title will be "The Golden Years - Teacher Education in western Canada, 19502000." It will document the parallel creation, rise, operation, and ultimate erosion of university-based teacher education programs in Alberta, British Columbia, Manitoba, and Saskatchewan in those decades. Hopefully it will be completed soon, while a few of the university, government, and professional people who made it all work are still available.

John Calam's Affecting Eternity is from that compendium.

\section{Review}

As is suggested above, in our time we have come to expect historical accounts, whether concerning politics, education, medicine, or other domains to highlight personal foibles, ad hominem disputes, vendettas, under-the-table agreements, and the like; Mencken without the wit. The 1950s were not entirely devoid of deprecatory tracts. For example, in 1953 Arthur Bestor wrote Educational Wastelands: The Retreat from Learning in Public Schools, Hilda Neatby wrote So Little for the Mind, and in 1955 Rudolf Flesch added Why Johnny Can't Read. But those publications do not reflect the spirit of those times, and it is that spirit that Calam captures in his account.

Ralph Waldo Emerson once remarked that the only true history lies in biography, and Calam was certainly influenced by that precept. He interweaves two themes in his account of the 1950s transformation of teacher education in British Columbia; one biographical and the other institutional. Calam blends them so seamlessly that a strong case can be made for reading the book twice, once for each strand.

See, for example, his account of Henry Johnson's role in the creation and operation of the Joint Board on pp. 88-94. Because I knew many of them, I can attest to the insight with which Calam incorporates material concerning the strengths and qualities of all those, not just Johnston, who proposed, designed, negotiated, compromised, and implemented the new faculty, all in a remarkably short period of time.

Beyond bringing the personal qualities of the protagonists to life, Calam uses them as icons for the agencies participating in the creation of the Faculty of Education; the provincial Department of Education, the administrations of both the University of British Columbia (UBC) and the University of Victoria, the British Columbia Teachers' Federation (BCTF), the existing post-baccalaureate school at UBC, the provincial Normal School in Vancouver, the newly-created Joint Board, and the cadre of school-of-education staff from the University of Manitoba. With local variations, the same agencies were involved in the parallel developments in the other western provinces.

We learn that the administration of the University of British Columbia was represented by the president, Norman MacKenzie, Walter Gage, a mathematician, future president, and almost-dean of the new faculty, Sperrin Chant, the Dean of Arts and Sciences, Leroi (commonly Roy) Daniells, the head of the department of English, and others. They wanted a professional faculty, responsible to the Board of Governors 
and the Senate that would complement their existing professional faculties.

The Department of Education, represented by Harold Campbell, the Chief Inspector of Schools, was another major player. Campbell's pronouncement, "I would just hate this new college to get off to a start with one clay foot," was widely quoted at the time and sums up well the spirit motivating those involved. Against a backdrop of what the other stakeholders desired, the department was determined to maintain control over teacher certification and to transform the Victoria Normal School into a parallel Faculty of Education at the University of Victoria. They compromised elsewhere, but on those two priorities they persisted and prevailed.

Calam's primary sources are understandably mainly from the universities and the Department of Education. He therefore skims over the contributions of some leaders from the profession like Alan Sprague, Eric Kelly, Hilda Cryderman, and Harold Parrott. He refers mainly to Charlie Ovans, the general secretary of the BCTF, because Ovans synthesized their views and conveyed to other agencies and persons involved the Federation's concern for full professional status for all teachers and a desire for direct Federation participation in both preparing students for practica and supervising them. Like all the other participating agencies, they compromised on some of their objectives.

For those interested in the roots of the mid-1950s transformation, Calam reaches back to an analysis circulated in 1925 by J. Harold Putman of Ottawa and George M. Weir, then the B.C. minister of Education, and some proposals from the 1940s and 1950s, including a significant one from Maxwell A. Cameron, the last director of UBC's after-degree program. But detailed planning for the new Faculty did not begin in earnest until March of 1955 with the passing of an amended University Act. Given a looming teacher shortage triggered in part by the baby boom, the action engaged immediately and September 1956 was set as the target date for enrolling the first students!

The first problem to be faced was that there was scarcely anywhere on campus to put either faculty members or classes. Some faculty and many classes were assigned to the refurbished army huts that Norman MacKenzie, Walter Gage, and Gordon Shrum had obtained from the Canadian military and had planted along the West Mall and in a nearby cluster. Others occupied a building transported from the Vancouver Normal school.

Staffing posed as great a problem. The faculty began with the small staff of the existing after-degree program, most of the staff of the Vancouver Normal school, some department personnel, and a few teachers, all before a dean had been appointed. To bring some order to the situation and to initiate program planning for the following September, in early 1956 the president's office named Henry Johnson as director of the elementary program and Ranton MacIntosh as director of the secondary program, both with substantial albeit pro-tem authority. In February Neville Scarfe was appointed as Dean. He arrived in June, bringing most of the University of Manitoba School of Education staff with him!

Calam examines well the turmoil attending the integration of such a diverse staff and the stress and compromises involved as they, Scarfe, MacIntosh, and Johnson 
learned to work together, shifting hour by hour from 'right now' emergencies to longer-term planning, all embedded in policies and practices that had had to be put in place before Scarfe's arrival so as to accommodate the students who would arrive in September.

Somehow it all worked. There is not, and can never be, a 'paper trail' documenting the largely ad hoc meetings and decisions that characterize those months. Anyone interested in recording more than Calam reports about that period would be well advised to document the reminiscences of the participants as soon as possible.

For two or three decades the Faculty flourished, and then began to change. In his last two chapters, particularly the last, Calam identifies the forces that caused Scarfe's Faculty to morph into something else. As we will see when the rest of "The Golden Years" is written, essentially the same forces transformed the Faculties of Education in the other western provinces at the same time and in parallel ways.

One of the more cogent of those forces stemmed from the fact that some faculty members in other parts of the university viewed askance the harijans with their bags of tricks who had come to masquerade as real professors. A common view, which influenced some later initiatives, was, "They belong in normal schools or community colleges, and if they must be associated with us, put them over in Burnaby somewhere."

Given that atmosphere, the Faculty and its professors had little option but to drift towards adopting university conventions and practices, whether they were suited to the Faculty's mandate or not. Calam documents in detail what they did and how they did it.

First, the Faculty made it a high priority to encourage faculty members who did not possess doctorates to obtain them, and to henceforth employ only persons with them. Of the forty-two faculty members in 1956, eleven had doctorates, seventeen had master's degrees, twelve had bachelor's degrees, and two had no degree. By 2006, all of the 126 members of the Faculty's academic departments possessed earned doctorates!

Second, Neville Scarfe had placed a high priority on student teaching. He held that practica ought to be the arenas for the synthesis of everything that student teachers learn, and that all faculty members ought to be directly involved in practica. But before long, as part of Joseph Schwab's 'flight to the periphery,' there began a flight from involvement in student teaching. In 1970 Clarence (Doc) Truax, the director of Student Teaching, reported that all 153 faculty members advised and supervised student teachers. In 1973 it was 78 of 199. By 2006 it was 1 (one), a faculty member doing practicum-related research!

At the same time, the focus of faculty scholarship changed. In the late 1950s, well over half of the faculty members were in unofficial Curriculum and Instruction and C. and I.-related departments. The bulk of their scholarship was addressed to the design, creation, delivery, and analysis of curricula.

But as the Faculty evolved, the focus of faculty and graduate student scholarship was redirected towards that of university social science departments. Bernard Shapiro recently summarized that transformation of scholarship in Education well when he 
observed that, not just in BC, we now see mainly second-rate philosophy, psychology, and sociology rather than first-rate curriculum studies. Shapiro's comment is timely and accurate.

But, consistent with his stance throughout, Calam's account of that phenomenon is much more in the mood of the 1950s. He ends by saying, "Change, however, should neither surprise nor daunt descendants of an institution shaped during an era of conflicting educational ideologies. Nor should it perplex participants acquainted with institutional solutions based on compromise." The thing is, where do we go from here? 
50 Historical Studies in Education/Revue d'histoire de l'éducation

\section{Blank \\ Left \\ Page}

